\title{
Corporate Governance and Firm Performance: The Role of Transparency \& Disclosure in Banking Sector of Pakistan
}

\author{
Rashid Zaman*, Muhammad Arslan, Muhammad Ayub Siddiqui \\ Bahria University Islamabad, PO box 44000, E-8, Islamabad, Pakistan \\ *Tel: 0092-311-8151850 \\ *E-mail address: rashidzamantanoli@gmail.com
}

\begin{abstract}
Purpose: This purpose of this paper is to empirically examine the relationship between transparency and disclosure and firm performance. Highlighting the importance of corporate governance in banking sector, the paper has focused in depth over its role, level and its impact on performance in banking industry of Pakistan. Design/methodology/approach: The paper access this purpose by constructing transparency and disclosure index for the past five year 2007-2011, using proxies for three sub-categories which are board and management structure disclosure, ownership structure disclosure and financial transparency disclosure. The paper also investigated structural changes of T\&D Index and its effect on bank financial performance over the sample of 30 banks operating in Pakistan. Findings: Empirical analysis results by using ordinary least square regression model, reveals that financial performance is positively related to the transparency and disclosure and their sub levels except ownership structure disclosure which has negative relation with both ROA and ROE. Furthermore the average T\&D level in Pakistani banking sector is above average. Practical implications: The current research paper aims for important policy implementation to reduce information asymmetry and improve corporate governance and firm performance in banking sector of Pakistan.
\end{abstract}

Keywords: Corporate Governance; Transparency \& Disclosure; Financial Performance; Agency Theory

\section{INTRODUCTION}

Effective disclosure of corporate governance practices leads the firm towards profitability and growth. Transparency and disclosure are core attributed of OECD, 1999 reports and also regarded as most important attributes in assessing the corporate governance practices across the globe. Recent big collapse such as Enron or World COM reveals the poor standard of disclosure in their financial statements and highlighted the importance of disclosure aspect in body of main research stream. Transparency and disclosure coupled with firm performance has largely studied on developed economy but very few studies were conducted on the developing countries especially Pakistan where the corporate governance infrastructure is in transformation phase after Security Exchange Commission of Pakistan launched its code of corporate governance in 2002 and revised it in 2012 for betterment of 
governance level in Pakistan. The core reason to analyze T\&D practices on banking industry is that it requires extra regulation for efficient working and also the whole economy revolves around this sector. The problem in the corporate governance arises from the asymmetry information and agency issues between managers and shareholders. These unresolved conflict badly impact on firm valuation (Chi \& Lin, 2000). The agency conflict is worse in economies having family oriented ownership structure and unfortunately major companies operating in Pakistan are family oriented firms. This set basic derive for the conduction of research that access the level of disclosure among companies and also highlight its impact on firm performance. Lang and Lundolm, (1993) claim that disclosure of corporate practices reduced this asymmetry of information and enables shareholders to effectively monitor management decision and firm performance. The current study aims for important policy implementation to reduce information asymmetry and improve corporate governance and firm performance in banking sector of Pakistan.

The purpose of the paper is to analyze the transparency and disclosure level in Pakistani banking industries and also determine their impact on financial performance of the banking sector. Empirical analysis has carried out using OLS multiple regression models over the sample of 30 banks for period of five year (2007-2011). Finding of the paper reveals that average level of disclosure in Pakistan is almost $79 \%$ which is quite impressive and furthermore the statistical result also determined that T\&D index along with its two sub level is significantly positively related to the financial performance indicators except ownership structure disclosure which is negative related to the ROA \& ROE.

The reminder of the paper is structured as follows. The next section provides brief overview of literature on transparency and disclosure and corporate governance infrastructure and its implication on Pakistani banking sector. This is followed by development of theoretical model and study hypothesis. The subsequent sections present the methodology, discussion and outcome of the study.

\section{LITERATURE REVIEW}

The large research has been conducted to assess the impact of corporate governance on firm performance for underdeveloped and developed markets. Transparent and value free disclosure of information is the key aspect of corporate governance in any organization. This transparent financial disclosure beside so many advantages attracts prospect investors to finance the investing opportunities. The importance of disclosure is substantively important to the investor because it reveal the common understanding about the organization understanding its structure, operations and processes. Shielfer \& Vishny (1997), John \& Senbet (1998) and Hermalin \& Weisbach, (2003) conduct studies on this area which provide extensive literature. Many Empirical studied has been conducted, highlighting the issue of disclosure on firm performance (Patel el al, 2002, Akhtaruddin, 2005; Attiya, et al., 2012; Barako, et al., 2006; Barako, 2007; Ben Ali, 2008; Hossain \& Reaz, 2007; Javid \& Iqbal, 2010). Financial performance of the bank and other institution can be measured by using ratio analysis, calculating performance against the allotted budget, sometimes by benchmarking or by combination of all these methods. (Avkiran, 1995). Most of the literature on bank performance describes the financial performance as the mode of earning high profit or return by minimizing the risk factor associated with the investment, this is the general relationship between the rate of return and interest rate risk which is higher the risk higher the return. Henry (2008) and Renders, et al (2010) studies suggested that good corporate governance 
practices could increase firm value. Dernev, et al (2005) associated a positive link between corporate governance and firm performance. In past various studies suggest an number of ways through which the corporate governance practices can be translated in to improved firm value like in studies by Hermalin, et al (2011). Their study result finding suggest that better price performance is associated with firm that have indicators of high disclose quality, having outside ownership concentration higher and firm which are focused rather that shows diverse.

\section{1. Corporate Governance \& Firm Performance}

Most of the empirical work which have been done on the analyzing the relationship between corporate governance and firm performance has been done from single control perspective like board size, CEO duality and audit committee. Arslan et al., (2014) examined the relationship of audit committee and CEO duality with firm performance by taking ROA and ROE as dimensions of firm performance. They argued that there is significant positive relationship between audit committee and firm performance while no significant relationship of CEO duality and firm performance (Arslan et al., 2014). (Brown \& Claylor, 2004) prepared governance score with 51 factors and, 8 sub categories for 2327 firms, which were based on the institutional shareholder service. The outcome of their study suggested that in those firm where governance are more valuable, gains more profitable and ultimately pay more cash to the shareholder. On the other hand Gompers,et.al.(2003) classified 24 governance factors into five sub categories like voting right, director protection, tactics for delaying hostile takeover ,other takeover defenses and state laws. Their finding indicates that firm with fewer shareholder rights have low firm value and lower stick return and it also shows that firm with stronger shareholder rights have higher firm value, higher profit, high sales growth, lower capital expenditure and they made few corporate acquisitions.

\section{2. Board \& Management Structure disclosures}

Othman, (2012) study used board and structure process disclosure (BSPD) as corporate governance attribute on measuring the level of performance. Their finding suggests that BSPD level effect is more on companies from financial sector than from non-financial sector. Furthermore BSPD level also act as useful tool for monitoring the board of directors' activities and characteristics. The literature review from the past studies shows that the limiting the board size will improve the firm performance. Board and management structure involves the disclosure of board size, its composition and disclosure about CEO Duality. Florackis, et al (2004) mention in their study that the board size of seven or eight members are effective. The larger board size will cause the agency theory conflict in which it is difficult to communicate and cost for monitoring and communication will be high in such types of the board. On the other hand it is expected that controlling and monitoring the small board size reduces the agency cost. The information disclosure is relatively high in small board size. The finding of Byard, et al (2006) supports our expectation. They study 1279 firms over two year (2001-2002) and they find that disclosure related to forecast information decreases with board size. Brown, et al (2004) finding also contributed the literature by analyzing that firm with board sizes between 6 and 15 have high ROE and high net profit margins with respect to other boards.

Board composition is very important for effectively monitoring of managers and reduction of agency cost (Choe, et al., 2003). There are some advantage of executive directors like in shape of skill, relative knowledge and expertise but for the sake of fresh ideas, objectivity and independency the role of independent director should be incorporated (Firth et 
al., 2002; Weir \& C , 1997). In addition , the agency theory also suggest that the non-executive director on the board will provide the higher disclosure of various aspect of company. The independent board will also lead the management to disclose information increasing transparency more than executive members, which highlight the importance of the independent board. The finding of (Chen, et al., 2000; Gul, et al., 2004) and Cheng, et al., (2006) all support of above expectation regarding independent director and finds that CEO duality has the impact on the firm performance. Their finding suggests those firms show better performance where the CEO and Chairman of board are separate over the firms having one person holding the both position. The separation of board chairman and CEO ultimately enhance the information disclosure.

\section{3. Ownership Structure Disclosure}

Agency theory focuses on the importance of ownership structure and its system in order to improve the governance. Three perspective of ownership can be sort out in any firm which director ownership, block ownership and institutional ownership. When director become shareholder the information disclosure will be less because they will not force management to disclose information (Jensen \& Meckling, 1976). Similarly the block owner have different proxies at the top management they are well aware of the policies and information and they will also not force the management to disclose the information. Therefore a negative relationship exists between the director ownership and block ownership with the information disclosure. This expectation is also supportive by (Chau, k, et al., 2002; Gompers et al., 2003) and (Eng, et al., 2003). Lakha, et al (2005) findings suggest that institutional investor relationship with disclosure is positively related since the ownership by institution shareholder will monitor the management more than small shareholder. They uses the foreign investor in his research as proxy for institutional investor.

\section{4. Financial Transparency and Information Disclosure}

The financial and transparency and disclosure has significant relation with the firm performance. Henry, (2008) and Renders, et al (2010) studies suggest that good corporate governance practices can increase firm value and Durnev, et al (2005) associated a positive link between corporate governance and firm performance. Iatridis, (2008) documented that disclosure provided in the annual reports always result in high profitably and leverage.

\section{5. Corporate Governance in Pakistan}

In recent years corporate governance has become promising area of research. The literature supports that corporate governance will ultimately improves the value of the firm. In this regard Cheema, (2003) suggest in their research that the good corporate governance can play a vital role in the economy of the Pakistan by attracting foreign investment and for mobilization of capital in the country. Arslan and Zaman (2014) determined the constraints and barriers in corporate governance and managerial efficiency. They documented that Pakistan has low ratios of factors like corruption, finance, gender and infrastructure which can create the problems. The researchers also suggests that proper implications of corporate governance can solve the problems (Arslan \& Zaman 2014). In Pakistan the majority of the business are family orientated which are acting for profit making. Which argues a greater challenge for policy makers to protect the dual objective, the minority shareholder and maintain the profit maximizing incentive of family oriented business. In this regard SECP and Institute of Chartered Accountant Pakistan as a joint effort launch the first code of corporate 
governance in early 2002 and make some amendment to tighten the rules, renewed and lunch recently in 2012.All the listed companies are required to comply their financial statement and procedure with the code.

The legal framework for companies is Companies Ordinance 1984, which sets rules for governance and regulation of the companies. Banks are regulated by the banking ordinance 1962 and SBP prudential issued time to time. The SECP code follows the good international practices, including listing rules including disclosure if price, annual general meeting. This code bounds companies to inform about the exchange the dividends, capital increase and changes in board, the accounting procedure, director remuneration, board independence, and other necessary things which are mandatory for disclosure. The State Bank of Pakistan (SBP) also mandated the code for all listed or non-listed banks and Development Finance Institutes (DFIs) in order to strengthen the shareholder and investor rights.

\section{6. Transparency \& Disclosure Index}

The substantive literature review about the phenomena of firm characteristics and T\&D index is widely included by so many firm characteristics according the financial disclosure extent by the compulsory and mandatory obligations. A number of prior studies have investigated determinants of companies' disclosure practices with consistency (Akhtaruddin, 2005; Attiya, et al., 2012; Barako, et al., 2006; Barako, 2007; Ben Ali, 2008; Hossain \& Reaz, 2007; Javid \& Iqbal, 2010a). The studies about the firm characteristics and extent of disclosure by (Akhtaruddin \& Haron, 2010; Hossain, 2008) used disclosure index with 101 mandatory item and 83 voluntary disclosure item for investigation of disclosure impact on different firm attributes The pragmatic study conducted Sandeep et al. (2002) used the 98 possible attributes of S\&P (Standard \& Poor's) for constructing T\&D index for further analyzation of T\&D score in 19 emerging markets. So disclosure level is subjective phenomena and depends up the law and infrastructure of the country under study. In order to measure the transparency and disclosure of the firm, the study constructed transparency and disclosure index for which the multifactor corporate rating is carried out. The construction of index is as follows for each bank there are there are 21 proxies selected in the annual report. Which are divided in to three sub categories: The sub categories contain six factors for board and management structure, seven for ownership and eight for financial transparency and disclosure. The weighting is based on the subjective judgment assigning the number 1 if it is complying with that proxy and 0 for not compliance. By taking the average of all sub category score we obtain transparency and disclosure index.

\section{THEORETICAL FRAMEWORK}

Jensen and Meckling, (1976) define agency relationship as a contract in which one party (the principal), gives another part (the agent) decision-making authority to perform some services on its behalf. But agency problem arise when each party wants to work for there own individual interests and when these interests diverge it creates the problem. Brennan, (1995) documented that agency conflict always indulged in creation of agency cost which occur to mitigate agency conflict. Ultimately this agency cost will impact on profitability of firm and transparency and disclosure. From the prospective of agency theory, problem in transparency and disclosure lies with asymmetry of information between managers and stakeholders. Agency theory serves on the concept of separation of owner and managers thus creating a principal and agent relationship among them (Sharma, 2013). One of the conflicts in agency 
theory between principal and agent arises due to having different approaches for profit maximization. Shareholder intent is to maximize their wealth but managers having more information look for the long run. This creates agency problem, which can be minimized by disclosing more information. Hossain, (2008) documented that firm having high profitability disclose more information than firms having little profit margin

Past literature of corporate governance revealed that CG can be used for building credibility, ensuring the transparency, accountability and keeping an effective source of information which should uplift good corporate governance (Patel, Balic, \& Bwakira, 2002).In most of previous studies the dimension to measure the corporate governance is board size, its composition and firm performance but in this study transparency and disclosure Index has been incorporated to measure corporate governance corporate. Financial performance of the bank is subject of shareholders/stakeholders interest so it can be calculated from the return on investment perspective and earnings ratios usually consist of two ratio which are ROA (return on asset) \& ROE (return on earning).

Independent Variable

\begin{tabular}{|l|}
\hline Transparency and disclosure Index \\
- \\
Board and management \\
structure disclosure \\
- Ownership structure \\
disclosure \\
- Financial information \\
disclosure \\
\hline
\end{tabular}

\section{Dependent Variable}

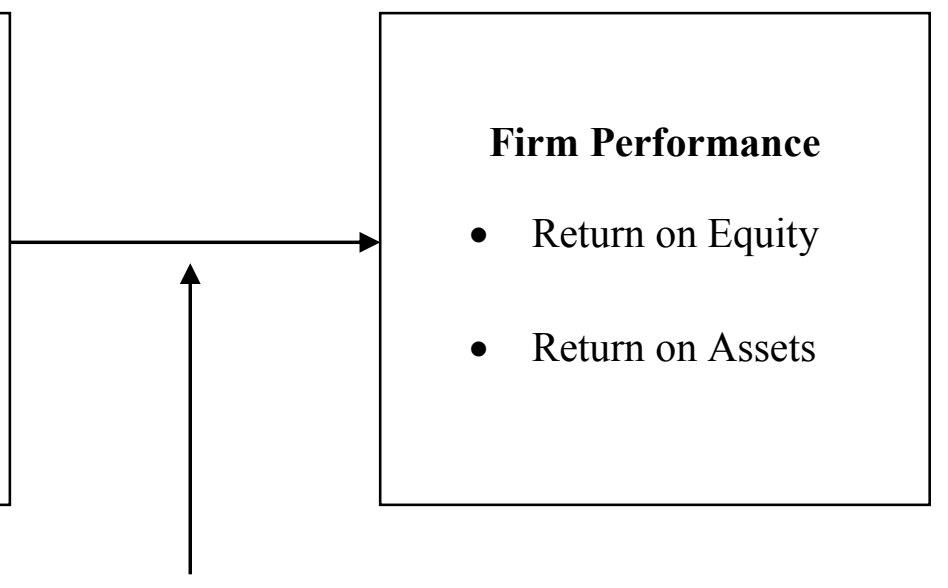

Control Variable

Firm Size

Fig. 1. Theoretical Model.

(Proposed theoretical model after reviewing literature)

\section{1. Hypothesis Development}

The literature concludes that disclosing the good corporate governance practices on both shareholders and stakeholder impacts positively on firm value (Ntim, et al., 2012). From literature concluded the following hypotheses

H1: Transparency and Disclosure index has positive impact on firm performance in banking sector of Pakistan.

The board and management structure plays a significant role in firm performance. The literature review from the past studies shows that the limiting the board size will improve the firm performance. Klein, et al. (2005) mention in their study that the board size of seven or 
eight members are effective. Callahan, et al. (2004) finding suggests that there is positive association between board structure and firm performance. So we concluded the following hypothesis for board composition and firm performance.

H2: Board \& Management structure disclosure has a positive impact on Firm performance in banking sector of Pakistan.

(Callahan, et al., 2004) documented that corporate governance disclosure practices in management decision and its analysis in annual report is associated with current and future performance and market valuation. Owner ship structure is negative associated with the firm performance because it measures the disclosure of block holder and share ownership of management. (Luo et al., 2006) findings suggest the negative association between current return and high management ownership concluding the hypothesis

H3: Ownership structure disclosure has the negative impact on firm performance in banking sector of the Pakistan.

The financial and transparency and disclosure has significant relation with the firm performance. Henry, (2008) and Renders, et al. (2010) studies suggest that good corporate governance practices can increase firm value and Durnev, et al. (2005) associated a positive link between corporate governance and firm performance. Chi, et al. (2008) suggests that disclosure practice can reduce information asymmetry which enable shareholder to monitor management decision and firm performance resulting the following hypothesis.

H4: Financial Transparency \& Information Disclosure has the positive impact on the financial performance in banking sector of the Pakistan

\section{RESEARCH METHODOLOGY}

\section{1. Sample \& Data Collection}

Financial sector for it complex and dynamic environment has attracted regulators and investor to keep an eye over its disclosure policies. The core reason behind i on financial sector is that it requires extra regulation for efficient working of this industry. The sample initially include the all banks operating in Pakistan, but availability of annual report which is main source of data gathering in this study was not found. Only sample of 30 banks over the period of five years 2007-2011 is used for data collection and empirical analysis.

\section{2. Model specification \& Variable measurement}

The following multiple transformed OLS regression model has been used for empirical investigation of relationship between T\&D Index and firm financial performance.

$$
\begin{aligned}
& \mathrm{ROA}=\beta 0+\beta 1 \text { TD_INDEX }+\beta 2 \text { F_SIZE }+\beta 3+\mathrm{e} \\
& \mathrm{ROE}=\beta 0+\beta 1 \text { TD_INDEX }+\beta 2 \text { F_SIZE }+\beta 3+\mathrm{e}
\end{aligned}
$$

Transformed OLS multiple regressions have been used for the following subcategories of corporate governance disclosure (OSE, FT and BM):

$$
\begin{aligned}
& \mathrm{ROA}=\beta 0+\beta 1 \mathrm{BM}+\beta 2 \mathrm{OSE}+\beta 3 \mathrm{FT}+\beta 4 \mathrm{~F} \_\mathrm{SIZE}+\mathrm{e} \\
& \mathrm{ROE}=\beta 0+\beta 1 \mathrm{BM}+\beta 2 \mathrm{OSE}+\beta 3 \mathrm{FT}+\beta 4 \mathrm{~F} \_\mathrm{SIZE}+\mathrm{e}
\end{aligned}
$$


Table 1. Description of Variables.

\begin{tabular}{|c|c|c|c|}
\hline Abbreviated Name & Full Name & Data Source & Measurement \\
\hline \multicolumn{4}{|l|}{ Dependent Variables } \\
\hline ROA & Return on Asset & Annual Report & Net income/Total Assets \\
\hline ROE & Return on Equity & Annual Report & $\begin{array}{c}\text { Net Profit / Shareholders } \\
\text { fund }\end{array}$ \\
\hline \multicolumn{4}{|l|}{ Independent Variables } \\
\hline TD_INDEX & $\begin{array}{c}\text { Overall Transparency \& } \\
\text { Disclosure Index }\end{array}$ & Annual Report & (Dichotomies 1,0) \\
\hline OSE & $\begin{array}{c}\text { Ownership structure } \\
\text { disclosure }\end{array}$ & Annual Report & (Dichotomies 1,0) \\
\hline FT & $\begin{array}{c}\text { Financial information } \\
\text { disclosure }\end{array}$ & Annual Report & (Dichotomies 1,0) \\
\hline $\mathrm{BM}$ & $\begin{array}{l}\text { Board \& management } \\
\text { structure disclosure }\end{array}$ & Annual Report & (Dichotomies 1,0) \\
\hline \multicolumn{4}{|l|}{ Control Variables } \\
\hline F_SIZE & Firm Size & Annual Report & Log of Total Assets \\
\hline
\end{tabular}

\section{2. 1. Transparency $\&$ disclosure Index}

The construction of transparency and disclosure index is subjective in nature as used by previous studies (Sandeep et al, 2002; Akhtaruddin \& Haron, 2010; Hossain, 2008). T\&D index construction involves total 21 proxies selected from the annual reports, which are divided in to three sub categories: The sub categories contain six factors for board and management structure, seven for ownership and eight for financial transparency and disclosure. The weighting is based on the subjective judgment assigning the number 1 if it is complying with that proxy and 0 for not compliance. By taking the average of all sub category score we obtain transparency and disclosure index.

\section{EMPIRICAL RESULT \& FINDINGS}

\section{1. Descriptive Statics}

The transparency and disclosure level of present banking sector in Pakistan has analyzed using the checklist of 21 disclosure items. Table 2 shows the descriptive analysis of variables incorporated in the study. The sample of 30 banks over the period of five year has employed in the study so the total number of observation remains 150 . By analyzing the Transparency and disclosure in table below, depicts the minimum and maximum level of banks is $48 \%$ and $95 \%$ respectively. The average result of overall disclosure is $79 \%$, which is quite impressive, while looking the governance infrastructure of the country. Board management and ownership structural disclosure is also more than $85 \%$. The average score for ownership structure disclosure is quite low (63\%) while comparing other sub categories and this score confirm the notion of the Pakistani companies structure as family oriented. Similarly the average score depicts that $11.5 \%$ assets in the Pakistani companies are held with banking sector. 
Table 2. Descriptive Statistics of Variables.

\begin{tabular}{|c|c|c|c|c|c|}
\hline Variable & $\mathrm{N}$ & Minimum & Maximum & Mean & Std. dev \\
\hline Dependent Variables & & & & & \\
\hline ROA & 150 & -10 & 4 & 0.53 & 2.29 \\
\hline ROE & 150 & -199 & 29 & -0.33 & 7.89 \\
\hline Independent Variables & & & & & \\
\hline TD_INDEX & 150 & 48 & 95 & 79.22 & 10.75 \\
\hline OSE & 150 & 29 & 100 & 63.89 & 11.67 \\
\hline FT & 150 & 50 & 100 & 87.5 & 13.15 \\
\hline BM & 150 & 67 & 100 & 86.23 & 11.55 \\
\hline Control Variables & & & & & \\
\hline F_SIZE & 150 & 8 & 12 & 11.15 & 0.839 \\
\hline
\end{tabular}

\section{2. Correlation Analysis}

Table 3 shows the correlation analysis between explanatory and dependent variables. The correlation matrix between $T \& D$ index and firm performance variables (ROA \& ROE) shows the significant positive relationship with each other $(r=0.49 \& 0.45)$, It depicts that firms having high transparency and disclosure level have also enjoy the high profit. Similarly board and management disclosure and financial information transparency disclosure, two sub clauses of T\&D Index is also positively related to financial performance. Ownership structural disclosure, sub clause of T\&D index is negatively associated with financial performance in the context of Pakistani banking industry due to family oriented ownership structure of majorities of firms in Pakistan.

Table 3. Pearson correlation matrix $(\mathrm{N}=150)$.

\begin{tabular}{|c|c|c|c|c|c|c|c|}
\hline Variable & ROA & ROE & TD_INDEX & OSE & FT & BM & F_SIZE \\
\hline ROA & 1.00 & 0.70 & 0.49 & -0.18 & 0.31 & 0.15 & 0.44 \\
\hline ROE & 0.70 & 1.00 & 0.45 & -0.02 & 0.21 & 0.22 & 0.43 \\
\hline TD_INDEX & 0.49 & 0.45 & 1.00 & 0.83 & 0.85 & 0.47 & 0.34 \\
\hline OSE & -0.18 & -0.02 & 0.83 & 1.00 & 0.52 & 0.72 & 0.28 \\
\hline FT & 0.31 & 0.21 & 0.85 & 0.52 & 1.00 & 0.41 & -0.11 \\
\hline BM & 0.15 & 0.22 & 0.47 & 0.72 & 0.41 & 1.00 & 0.02 \\
\hline F_SIZE & 0.44 & 0.43 & 0.34 & 0.28 & -0.11 & 0.02 & 1,00 \\
\hline
\end{tabular}

\section{3. Regression Result}

OLS Regression results shown in table 4 states that transparency and disclosure index is significant positive related to the indicators of firm performance that are return on assert 
(ROA) and return on equity (ROE). The value of F-test shows that the model is best fit to data and Durbin Watson statistics shows that there are not significant serial correlation are present among the variables. According to confidence interval approach the t-value and $p$-value stratifying the relationship between ROA, ROE and T\&D index are at significant level $(\mathrm{t}=$ $2.295 \&$ P-value $=0.0054$ ) which support the first hypothesis of study (H1) that there is positive relationship between transparency $\&$ disclosure and firm financial performance. Our result regarding T\&D and firm performance are supported by previous studies. (Owusu \& Yeoh, 2005 \& Ntim, et al., 2012).

Table 4 also shows the econometric result of relationship of three sub level of transparency and disclosure with firm performance. By analyzing the result for board management structure process disclosure with firm financial performance indicators (ROA \& $\mathrm{ROE})$, it is observed that all statistical values $(\mathrm{t}=2.105 \& \mathrm{P}=0.0051)$ are documenting positive relationship among them. So our second proposed hypothesis (H2) has accepted that there exist, positive relationship between board \& management structure disclosure and financial performance supported by the studies conducted by Florackis and Ozkan (2004) and Klein, et al. (2005).

For the relationship between ownership structure disclosure and firm financial performance (H3) indicators, there exists a negative relationship between them. The confidence interval value of $t$-statistics $(t=-2.47 \&-3.82)$ and probability statistics $(P=0.009$ $\& 0.004)$ confirmed the significant negative relation between ownership structure disclosure and ROA and ROE respectively. The negative relations between these variables also depict the notion that companies often not willing to disclose the proper information about major owners/shareholders or most firms in Pakistan are family oriented. These statistical result are in line with the studies conducted by as Callahan, et al. (2004) and Luo, et al. (2006), in which they documented negative relationship between ownership structure and firm performance.

In terms of financial information disclosure, the regression results listed in table 4 support the proposed hypothesis (H4) that financial information disclosure a (sub level of T\&D) is significant positive related to the firm financial performance when size is taken as control variables. The coefficient estimate is significant to ROA and ROE at $1 \%$ significant level. Henry, (2008) and Renders, et al. (2010) also documented in their studies that companies disclosing more information in their annual reports will enhance their shareholder confidence and ultimately this will impact upon their performance. In relation to our control variable of the study, table 4 result reveals that firm size is an important predator of the firm profitability. Larger firm willing to disclose more information as they are regularly watched and monitored by regulators and ultimately enjoy the benefits of these disclosure by establishing trust/confidence of customers and shareholders in terms of profitability.

Table 4. Ordinary least squares (OLS) regression results of Transparency \& Disclosure scores on test $\&$ Control variables $(\mathrm{N}=150)$.

\begin{tabular}{|c|c|c|}
\hline $\begin{array}{c}\text { Dependent } \\
\text { Variable }\end{array}$ & Return on Assets (ROA) & Return on Equity (ROE) \\
\hline Adjusted $\mathrm{R}^{2}$ & $57.69 \%$ & $28.02 \%$ \\
\hline F-Value & 15.12 & 6.34 \\
\hline P-value & $0.0046^{* * *}$ & $0.003^{* * *}$ \\
\hline $\begin{array}{c}\text { Durbin Watson } \\
\text { Stat }\end{array}$ & 1.88 & 1.74 \\
\hline
\end{tabular}




\begin{tabular}{|c|c|c|c|c|c|c|}
\hline Parameters & $\begin{array}{c}\text { Coeff. } \\
\text { Est }\end{array}$ & t-statistics & P-Value & $\begin{array}{c}\text { Coeff. } \\
\text { Estd. }\end{array}$ & t-statistics & P-Value \\
\hline Intercept & Included & & & Included & & \\
\hline H1TD_INDEX & 0.42 & 2.295 & $0.0054^{* * *}$ & 0.39 & 2.149 & $0.0044^{* * *}$ \\
\hline H2-BM & 0.46 & 2.105 & 0.0051 & 0.41 & 2.002 & 0.0069 \\
\hline H3-OSE & -0.984 & -2.476 & $0.0009^{* * *}$ & -1.02 & -3.82 & $0.004^{* * *}$ \\
\hline H4-FT & 11.95 & 2.639 & $0.0097^{* * *}$ & 8.07 & 2.01 & $0.002^{* * *}$ \\
\hline $\begin{array}{c}\text { F_SIZE } \\
\text { (Control) }\end{array}$ & 0.31 & 3.591 & $0.028^{* *}$ & 0.28 & 2.915 & $0.0417^{* *}$ \\
\hline
\end{tabular}

Shows significance level $* * *$ at $1 \%, * *$ at $5 \%$, and $* *$ at $10 \%$

\section{CONCLUSIONS}

Transparency and disclosure coupled with firm performance has been largely studied on developed economy but very few studies were conducted on the developing countries especially Pakistan where the corporate governance infrastructure is in transformation phase after Security Exchange Commission of Pakistan launched its code of corporate governance in 2002 and revised it in 2012 for betterment of governance level in Pakistan. The reason behind the sample related to financial sectors is due to its sensitive nature and second most of economy revolves around this sector. The purpose of this research paper is to determine the level of disclosure and its impact on financial performance on banking system. The construction of T\&D index in the paper involves the multifactor corporate rating, based on the annual reports of banks operating in Pakistan. Furthermore index follows 21 disclosure proxies taken from literature, divided in to three sub categories which are board \& ownership structure disclosure, ownership structure disclosure and financial information OLS transformed regression has employed on the sample of 30 banks over the period of five year (2007-2011).

Finding of the paper reveals that T\&D index along with its two sub level is significantly positively related to the financial performance indicators (ROA \& ROE) except ownership structure disclosure which is negative related to the ROA \& ROE and finally the average level of disclosure is at higher side for Pakistani banking industry.

The current research paper aims for important policy implementation to reduce information asymmetry and improve corporate governance and firm performance in banking sector of Pakistan High level of transparency and disclosure can be used as trust improvement tool in order to maximize the worth of the organization. This study suggests that minimum disclosure level of the company should be above requirement of regulator in order to cope disclosure benefits. The research paper also poses some limitation. First is regarding sample size, which is small due to availability of data and time constraint. Second limitation is regarding the construction of transparency and disclosure index due to its subjective nature and data presented by companies in their annual reports may have some questions. 


\section{References}

[1] Arslan, M., Zaman, R., Malik, R. K. \& Mehmood, A. (2014). Impact of CEO Duality and Audit Committee on Firm Performance: A Study of Oil \& Gas Listed Firms of Pakistan. Research Journal of Finance and Accounting, 5, 151-156.

[2] Arslan, M. \& Zaman, R. (2014). Constraints and Barriers in Corporate Governance and Managerial Efficiency: A Comparative Analysis. Developing Country Studies, 4, 83-94.

[3] Attiya, Javid, \& Iqbal. (2012). Ownership Concentration, Corporate Governance and Firm Performance: Evidence from Pakistan. Pakistan Institute of Development Economics.

[4] Akhtaruddin \& Haron (2010). Board ownership, audit committees, effectiveness and corporate voluntary disclosures. Asian Review of Accounting, 18(1), 68-82.

[5] Akhtaruddin. (2005). Corporate mandatory disclosure practices in Bangladesh. International Journal of Accounting, 40(4), 399-422.

[6] Anderson, R, Mansi, S., \& Reeb, D. (2004). Board Characteristics, Accounting Report Integrity, and The Cost of Debt. Journal of Accounting and Economics, 37, 315-342.

[7] Avkiran, N. K. (1995). Developing an instrument to measure customer service quality in branch banking. International Journal Of Banks Marketing, 12(6),10-18.

[8] Barako. (2007). Determinants of voluntary disclosures in Kenyan companies annual reports. African Journal of Business Management, 1(5), 113-128.

[9] Barako, Hancock, P., \& Izan, H. Y. (2006a). Relationship between corporate governance attributes and voluntary disclosures in annual reports: The Kenyan experience. Financial Reporting Regulation and Governance, 5(1), 1-25

[10] Ben Ali, C. (2008). Disclosure quality and corporate governance: Evidence from the French stock market. Paper presented at the The British Accounting Association Annual Conference, Blackpool, UK.

[11] Brown, D, L., \& Claylor, M. L. (2004). Corporate Governance and Firm Performance. Working Paper. Gorgia State University, USA.

[12] Byard, D, Li, Y, Weintrop, \& J. (2006). Corporate governance and the quality of financial analysts' information. Journal of Accounting and Public Policy, 25(5), 609-625.

[13] Callahan, C, Smith, \& R. (2004). Firm performance and management's discussion and analysis disclosures: An industry approach. Working paper. University of Arkansas.

[14] Chau, K, G., Gray, \& J, S. (2002). Ownership structure and corporate voluntary disclosure in Hong Kong and Singapore. The International Journal of Accounting, 37, 247-265.

[15] Cheema, \& A. (2003). Corporate Governance in Pakistan: Issues and Concerns. The Journal, 8(2).

[16] Chen, P, C. J., Jaggi, \& B. (2000). Association between independent non-executive directors, family control and financial disclosures in Hong Kong Policy. Journal of Accounting and Public Policy, 19, 285-310.

[17] Cheng, M, E. C., Courtenay, \& M, S. (2006). Board composition, regulatory regime and voluntary Disclosure. International Journal of Accounting, 41(3), 262-289.

[18] Chi, C, L., Lin, \& Y, Y. (2008). A study on the factors influencing the information disclosure $\&$ transparency rating system. Paper presented at the international conference on global business theoretical and empirical works Providence University.

[19] Choe, H, Lee, \& BS. (2003). Korean bank governance reform after the Asian financial crisis. Pacific-Basin Finance Journal, 11(4), 483-508. 
[20] Drobetz, W., Schillhofer, A., \& Zimmermann, H. (2004). Corporate governance and expected stock returns: evidence from Germany. European Financial Management, 10, 267-293.

[21] Durnev, Kim, A., \& H, E. (2005). To steal or not to steal: Firm attributes, legal environment, and valuation. Journal of Finance, 60, 1461-1493.

[22] Eng, L, L., Mak, \& T, Y. (2003). Corporate governance and voluntary disclosure. Journal of Accounting and Public Policy, 22, 325-345.

[23] Firth, M, Fung, PMY, Rui, \& OM. (2002). Simultaneous relationships among ownership, corporate governance and firm performance.

[24] Florackis, C, Ozkan, \& A. (2004). Agency costs and corporate governance mechanisms: Evidence for UK firms.

[25] Gompers, P, Ishii, L., \& Metrick, A. (2003). Corporate Governance and Equity Prices. Quarterly Journal of Economics, 107-155.

[26] Gul, A, F., Leung, \& S. (2004). Board leadership, outside directors' expertise and voluntary corporate disclosures. Journal of Accounting and Public Policy 23, 1-2.

[27] Hakim Ben Othman (2012). "The effect of board structure and process disclosure on corporate performance in the emerging African markets", Managerial Auditing Journal, $27(2), 156-174$

[28] Henry, D. (2008). Corporate governance structure and the valuation of Australian firms: Is there value in ticking the boxes? Journal of Business Finance \& Accounting, 35, 912-942.

[29] Hermalin, E, B., Weisbach, \& S, M. (2011). Information disclosure and corporate governance, Journal of Finance, Forthcoming.

[30] Hermalin, B., \& Weisbach, M. (2003). Board of Directors as an Endogenously Determined Institution: A Survey of the Economic Literature. Economic Policy Review, 9, 7-26.

[31] Hossain. (2008). The Extent of Disclosure in Annual Reports of Banking Companies: The Case of India. European Journal of Scientific Research, 23(4), 659-680.

[32] Hossain, \& Reaz, M. (2007). Determinants and characteristics of voluntary disclosure Indian banking companies. Corporate Social Responsibility and Environmental Management, 14(5), 274-288.

[33] Iatridis. (2008). Accounting disclosure and firms' financial attributes: Evidence from the UK stock market. International Review of Financial Analysis, 17(2), 219-241.

[34] Jensen, M, \& Meckling, W. (1976). Theory of the Firm: Managerial Behaviour, Agency Costs, and Ownership Structure. Journal of Financial Economics, 3, 305-360.

[35] John, K., \& Senbet, L. W. (1998). Corporate Governance and Board Effectiveness Journalof Banking and Finance 22, 371-403.

[36] Klein, P, Shapiro, D., \& Young, J. (2005). Corporate Governance, Family Ownership and Firm Value. Corporate Governance, 13.

[37] Lakhal, \& F. (2005). Voluntary earnings disclosures and corporate governance: Evidence from France. Review of Accounting and Finance, 4(3), 64-85.

[38] Lang, M., \& Lundholm, R. (1993). Cross-sectional determinants of analysts ratings of corporate disclosures, Journal of Accounting Research, 31, 246271.

[39] Lang, M., \& Lundholm, R. (1996). Corporate disclosure policy and analyst behavior, The Accounting Review, 71, 467-492.

[40] Luo, S, Courtenay, SM, Hossain, \& M. (2006). The effect of voluntary disclosure, ownership structure and proprietary cost on the return-future earnings relation. PacificBasin Finance Journal, 15(5), 501-521. 
[41] Luo, S., Courtenay, SM, \& Hossain, M. (2006). The effect of voluntary disclosure, ownership structure and proprietary cost on the return-future earnings relation. PacificBasin Finance Journal, 14(5), 501-521.

[42] Ntim, C. G., Opong, K. K., \& Danbolt, J. (2012). The Relative Value Relevance of Shareholder versus Stakeholder Corporate Governance Disclosure Policy Reforms in South Africa. An International Review, 20(1), 84-105.

[43] Owusu, \& Yeoh. (2005). The effect of legislation on corporate disclosure practices. ABACUS, 41(1), 92-109.

[44] Patel, S. A., Balic, A., \& Bwakira, L. (2002). Measuring transparency and disclosure at firmlevel in emerging markets. Emerging Markets Review, 3, 325-337.

[45] Renders, A., Gaeremynck, A., \& Sercu, P. (2010). Corporategovernance ratings and performance: a cross-European study. Corporate Governance. An International Review, $18,87-106$.

[46] Sharma, N. (2013). Theoretical Framework for Corporate Disclosure Research. Asian Journal of Finance \& Accounting, 5(1).

[47] Shleifer, A., \& Vishny, R. (1997). A Survey of Corporate Governance. Journal of Finance, 52, 737783.

[48] Weir, \& C. (1997). Corporate governance, performance and take-overs: An empirical analysis of UK merges. Applied Economics, 29, 1465-1475.

\section{Appendix 1 \\ Transparency \& Disclosure Index (T\&DI) Components}

Sub Index 1: Board \& Management Structure Disclosure

(i) Board size

(ii) Board composition

(iii) CEO and Chairman Separation

(iv) Independent Director in the board

(v) Existing of position of CFO

(vi) AGM

\section{Sub Index 2: Ownership Structure Disclosure}

(i) Does CEO owns share

(ii) Director ownership other than CEO \& chairman

(iii) Chairman \& CEO is block ownership(more than $10 \%$ shareholding)

(iv) Concentration of ownership(Top five)

(v) Outside Block holder

(vi) Dividend Policy

(vii) Staff benefits other than wages \& Salaries 


\section{Sub Index 3: Financial Transparency and Information Disclosure}

(i) Does company having full disclosure of CG practices

(ii) Does the company discloses how much it pays to auditor for consulting and other work

(iii) Does the company disclose full biography of its board members

(iv) Disclosure of director and executive staff remuneration

(v) Disclosure of share ownership according to the requirement of code

(vi) Employee ownership (executive management staff member)

(vii) Disclosure of internal audit committee

(viii) Accounting policies 